2014

\title{
The Gardener Site (41CP55): A Late Caddo Settlement on Big Cypress Creek in East Texas
}

Timothy K. Perttula

Heritage Research Center, Stephen F. Austin State University

Bo Nelson

Heritage Research Center, Stephen F. Austin State University

Robert Z. Selden Jr.

Heritage Research Center, Stephen F. Austin State University

Follow this and additional works at: https://scholarworks.sfasu.edu/ita

Part of the American Material Culture Commons, Archaeological Anthropology Commons, Environmental Studies Commons, Other American Studies Commons, Other Arts and Humanities Commons, Other History of Art, Architecture, and Archaeology Commons, and the United States History Commons

Tell us how this article helped you.

This Article is brought to you for free and open access by the Center for Regional Heritage Research at SFA ScholarWorks. It has been accepted for inclusion in Index of Texas Archaeology: Open Access Gray Literature from the Lone Star State by an authorized editor of SFA ScholarWorks. For more information, please contact cdsscholarworks@sfasu.edu. 


\section{The Gardener Site (41CP55): A Late Caddo Settlement on Big Cypress Creek in}

East Texas

\section{Creative Commons License}

\section{(c) (1) \&}

This work is licensed under a Creative Commons Attribution-NonCommercial 4.0 International License 


\title{
The Gardener Site (41CP55): A Late Caddo Settlement on Big Cypress Creek in East Texas
}

\author{
Timothy K. Perttula, Bo Nelson, and Robert Z. Selden, Jr.
}

\section{INTRODUCTION AND SITE SETTING}

The Gardener site (41CP55) in Camp County, Texas, was first recorded by Sullivan (1977) prior to construction of Lake Bob Sandlin on Big Cypress Creek. A surface collection of sherds and daub suggested that the site was the locus of a Late Caddo period (ca. A.D. 1450-1680) settlement and burned house (see Thurmond 1990:56). However, no further archaeological work was done at the site before it was inundated by Lake Bob Sandlin in the late 1970s.

Recently, because of lower flood pool levels at Lake Bob Sandlin due to East Texas drought conditions, archaeological materials from the Gardener site have been exposed along the shoreline of the lake. This article concerns the documentation of a substantial aboriginal artifact assemblage collected from the shoreline surface of the site.

The Gardener site is located along an upland slope (330 ft. amsl) on the west side of Picket Spring Branch, a small and northward-flowing tributary to Big Cypress Creek, in the Post Oak Savanna. The old channel of Big Cypress Creek lies approximately $1.8 \mathrm{~km}$ north of the site. The overall extent of the site is not known, although Thurmond (1990:56) suggests it is relatively small.

\section{ARTIFACT ASSEMBLAGE}

The artifact assemblage we have documented from the Gardener site contains an assortment of stone and ceramic artifacts. This includes chipped and ground stone tools $(n=71)$, lithic debris and cores $(n=1721)$, fire-cracked rock $(n=1)$, plain and decorated sherds $(n=617)$ from a number of broken ceramic vessels, a portion of a single brushed ceramic vessel, and large and well-preserved pieces of daub $(n=69)$. The daub is evidence that there is at least one burned Caddo structure at the site.

\section{CHIPPED STONE TOOLS}

\section{Arrow Points and Arrow Point Preforms}

Arrow points $(n=20)$ and arrow point preforms $(n=5)$ are abundant at the Gardener site, indicating that the manufacture and use of arrow points was common at the site for hunting purposes. In addition to eight quartzite blade fragments, the typologically identifiable arrow points $(n=12)$ are exclusively post-A.D. 1550 Titus phase styles; they are also made from local quartzite. They include Bassett ( $n=2$, Figure 1), Maud ( $\mathrm{n}=8$, Figure 2), and Talco (n=2, Figure 3) types.

The five arrow point preforms are made from local quartzite $(n=3)$, gray chert $(n=1)$, and dark gray novaculite $(n=1)$. Between the arrow points and arrow point preforms, $92 \%$ of these points have been made from local quartzite, and the remainder are on non-local chert and novaculite. 

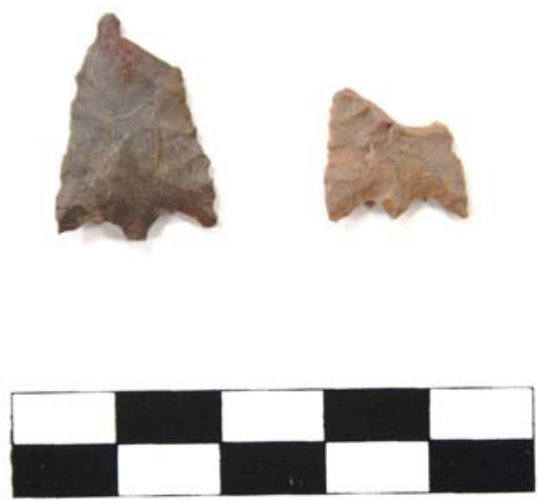

Figure 1. Bassett points from the Gardener site.
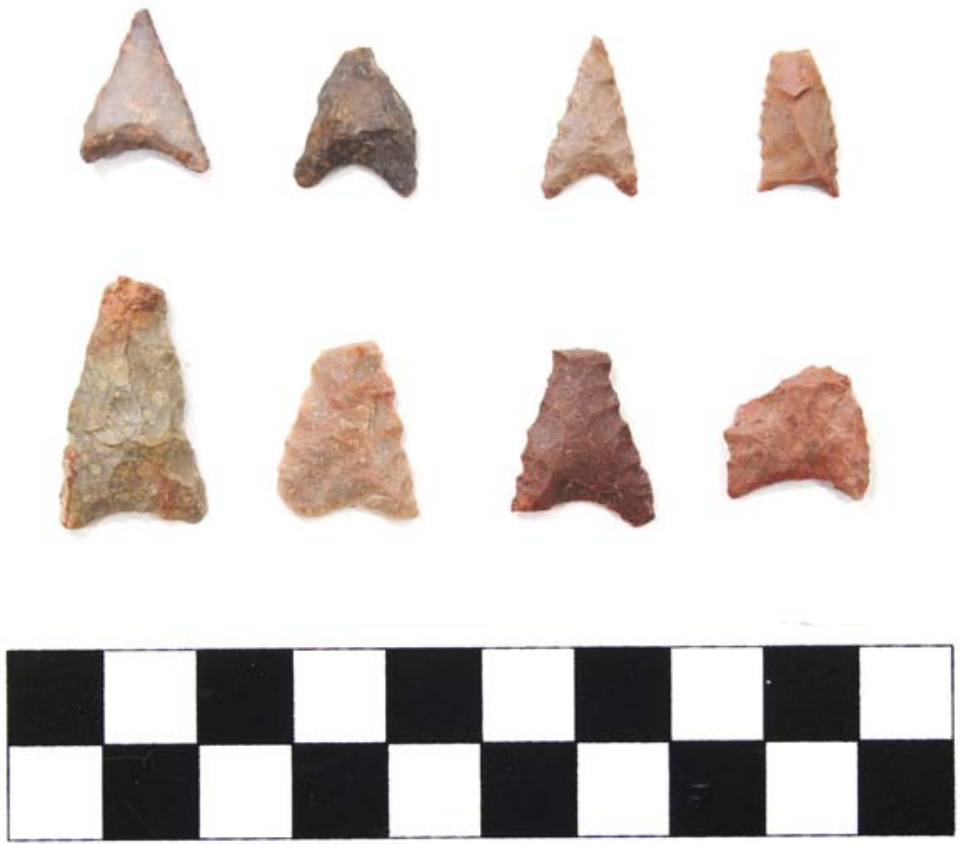

Figure 2. Maud points from the Gardener site.
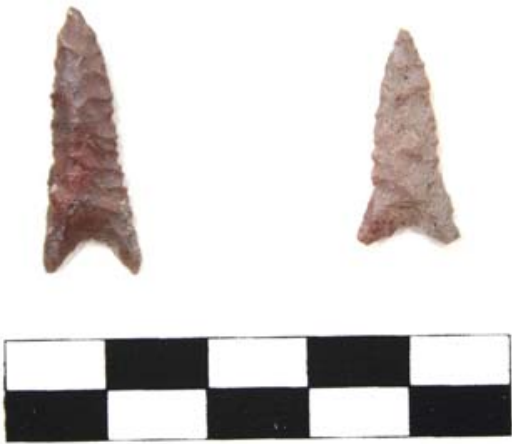

Figure 3. Talco points from the Gardener site. 


\section{Dart Points}

There are three dart points in the assemblage from the Gardener site, an unidentified stem fragment of quartzite, a quartzite Ellis point, and a white novaculite expanding stem-corner-notched fragment that may be a Williams point (Figure 4). These points suggest a limited use of the site during the Late Archaic and Woodland periods.

\section{Bifaces}

Both early and late stage bifaces and bifacial tool fragments are in the Gardener site chipped stone assemblage (Table 1). More than $92 \%$ of the bifaces are made from local quartzites, and one tool fragment is made from a non-local gray novaculite.
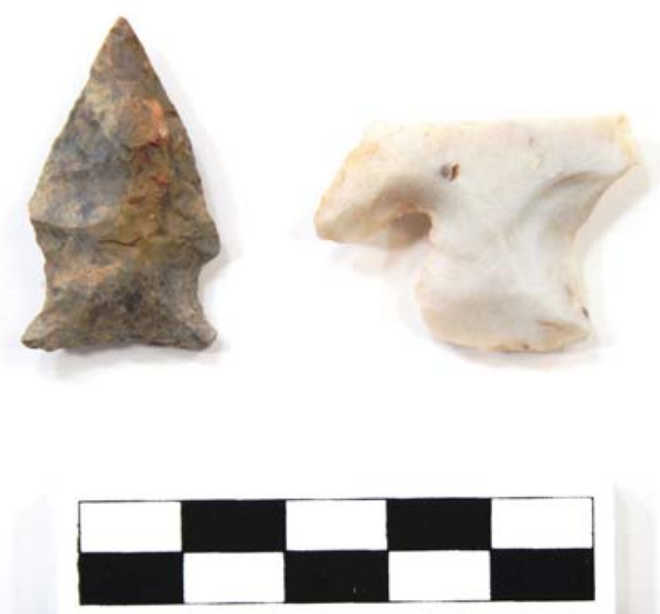

Figure 4. Dart points from the Gardener site: left, Ellis; right, cf. Williams.

Table 1. Bifaces from the Gardener site.

\begin{tabular}{lcccc}
\hline Form & Quartzite & $\begin{array}{c}\text { Petrified } \\
\text { wood }\end{array}$ & $\begin{array}{c}\text { Gray } \\
\text { novaculite }\end{array}$ & $\mathrm{N}$ \\
\hline $\begin{array}{l}\text { Early stage } \\
\text { Late stage/ } \\
\text { indeterminate } \\
\text { Bifacial tool fragment }\end{array}$ & 9 & 1 & - & 10 \\
\hline Totals & 13 & - & - & 13 \\
\hline
\end{tabular}

Flake Tools

All of the flake tools $(n=14)$ from the Gardener site are on local quartzite. These include 12 tools with use wear and/or retouch along one flake edge, and two tools with bilateral use wear and/or retouch. These expedient tools would have been used for light duty cutting, scraping, and shredding. 


\section{Scraper}

The one side scraper from the site has a steep working edge along the side of a flake of local quartzite.

\section{Gouge}

One ferruginous sandstone gouge is in the collection from the Gardener site (Figure 5). The chipped stone tool has a unifacial working edge, and one face of the tool has remnants of polishing wear.
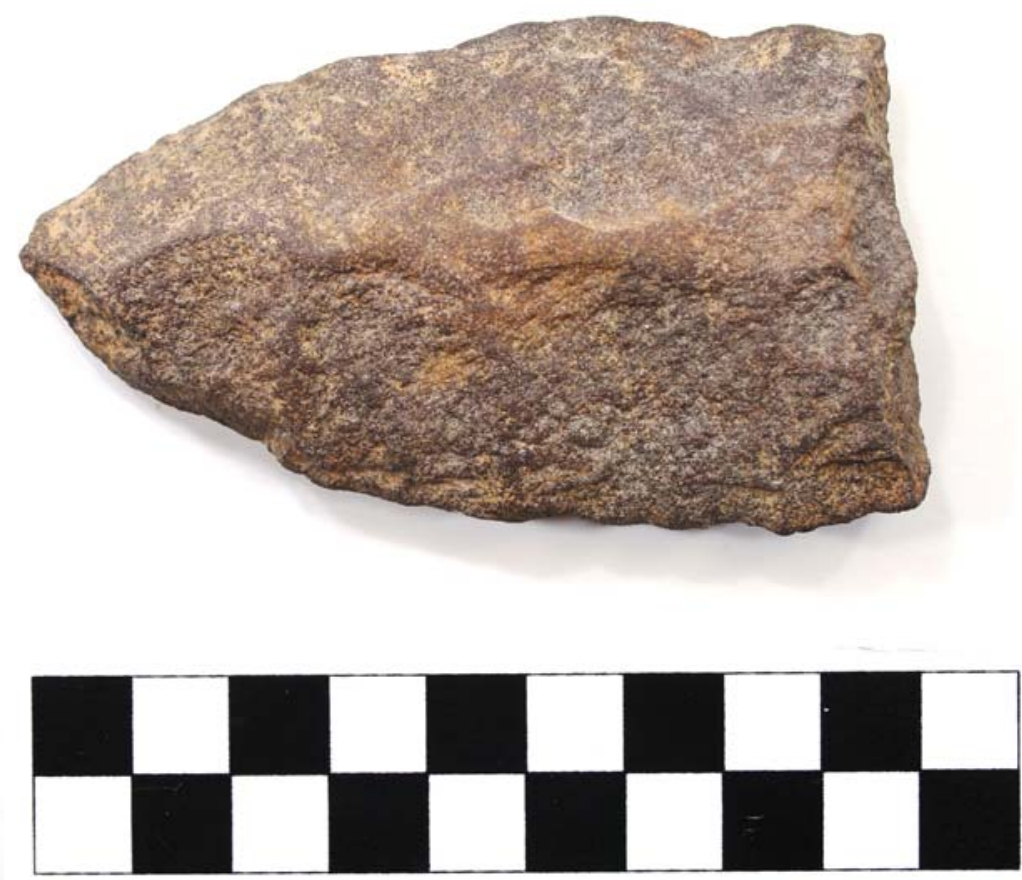

Figure 5. Chipped stone gouge from the Gardener site.

\section{CHIPPED STONE LITHIC DEBRIS AND CORES}

The lithic debris and cores from the Gardener site are dominated by local coarse- and fine-grained quartzite. Quartzite accounts for $92 \%$ of the lithic debris and cores (Table 2), and local quartzite, cherts, petrified wood, hematite, and ferruginous sandstone comprise almost $95 \%$ of this part of the chipped stone assemblage. Cherts (particularly a gray chert) considered likely to be of non-local origin comprise $3.8 \%$ of the debris and cores, and novaculite (ultimately originating in the Ouachita Mountains in southeastern Oklahoma) comprises another $1.5 \%$ (Table 2).

The percentage of lithic debris in the assemblage as a whole with cortical remnants is a substantial $69.2 \%$, including $70.8 \%$ of the debris from local lithic raw materials (see Table 2). This suggests that much of the knapping done at the Gardener site is a product of the reduction of pebble-sized pieces of raw material gathered in nearby stream gravels, probably to obtain flakes of suitable size for chipped stone tool manufacture.

There is also a relatively high percentage of cortical flakes (34.6-45.3\%) among the cherts and novaculite thought to be of non-local provenance (see Table 2). This may indicate that pebbles of these materials actually comprise a small proportion of the local gravels, and thus are not truly of non-local 
Table 2. Lithic debris and cores from the Gardener site.

\begin{tabular}{|c|c|c|c|c|}
\hline Raw Material & Lithic Debris & $\%$ Cortical & Cores & $\mathrm{N}$ \\
\hline Quartzite & 1517 & 71.1 & 61 & 1578 \\
\hline Petrified wood & 20 & 50.0 & 1 & 21 \\
\hline Ferruginous sandstone & 3 & 33.3 & - & 3 \\
\hline Hematite & 2 & 100.0 & - & 2 \\
\hline Brown chert & 6 & 83.3 & 1 & 7 \\
\hline Red chert & 19 & 73.7 & - & 19 \\
\hline Subtotal & 1567 & 70.8 & 63 & 1630 \\
\hline Black chert & 1 & 100.0 & - & 1 \\
\hline Dark brown chert & 1 & 100.0 & - & 1 \\
\hline Gray chert & 49 & 44.9 & 1 & 50 \\
\hline Dark gray chert & 10 & 40.0 & - & 10 \\
\hline Light gray chert & 1 & - & - & 1 \\
\hline White chert & 2 & 50.0 & - & 2 \\
\hline Subtotal & 64 & 45.3 & 1 & 65 \\
\hline Brown novaculite & 1 & 100.0 & - & 1 \\
\hline Gray novaculite & 16 & 18.8 & - & 16 \\
\hline White novaculite & 1 & - & - & 1 \\
\hline Orange novaculite & 4 & 50.0 & - & 4 \\
\hline Yellow novaculite & 4 & 75.0 & - & 4 \\
\hline Subtotal & 26 & 34.6 & - & 26 \\
\hline Totals & 1657 & 69.2 & 64 & 1721 \\
\hline
\end{tabular}

origin. The other possibility is that these raw materials were cortex-covered cores and tools when they were transported to the Gardener site, and their further reduction on site generated a significant quantity of cortex-covered flakes.

All but one of the cores from the Gardener site are on local lithic raw materials, with more than 95\% of the cores on quartzite (Table 3). The cores are the product of the reduction of pebble-sized pieces of raw material through a variety of platforms to obtain flakes for tool manufacture.

\section{GROUND STONE TOOL}

There is a single ground stone tool in the Gardener site assemblage. This is a grinding slab made from a local coarse-grained quartzite.

\section{CERAMIC SHERDS}

\section{Plain Sherds}

The 285 plain sherds from the site includes nine rims, 260 body sherds, and 16 base sherds. Approximately $90 \%$ of these sherds are from grog-tempered vessels, and $9.1 \%$ of the sherds are from bone-tempered vessels. One of the plain rims is from a bottle and another is from a jar with rim peaks. 
Table 3. Cores from the Gardener site.

\begin{tabular}{lcccc}
\hline Core type & \multicolumn{2}{c}{ Raw Material } \\
& Quartzite & $\begin{array}{c}\text { Petrified } \\
\text { wood }\end{array}$ & $\begin{array}{c}\text { Brown } \\
\text { chert }\end{array}$ & $\begin{array}{c}\text { Gray } \\
\text { chert }\end{array}$ \\
\hline Core fragment & 12 & - & - & - \\
Tested pebble & 2 & - & - & - \\
Single platform & 22 & - & 1 & 1 \\
Multiple platform & 21 & - & - & - \\
Bi-directional & 1 & 1 & - & - \\
Bifacial & 1 & - & - & - \\
Bipolar & 2 & 1 & - & 1 \\
\hline Totals & 61 & & 1 & \\
\hline
\end{tabular}

The plain to decorated sherd ratio for the assemblage is 0.86 . This high proportion of decorated sherds from the site is consistent with a Late Caddo Titus phase ceramic assemblage in the mid-Big Cypress Creek basin. Plain rims comprise $19 \%$ of the 48 rims in the assemblage; $54 \%$ of the rims are from utility wares, and the remaining $27 \%$ of the rims are from fine wares (see below).

\section{Decorated Sherds}

Both utility wares and fine wares are well represented in the Gardener site vessel ceramics (Table 4). The utility wares comprise $84 \%$ of the decorated sherds, especially sherds with brushing marks, including $67 \%$ of the decorated rim sherds.

Table 4. Decorated sherds from the Gardener site.*

\begin{tabular}{llll}
\hline Decorative Method & Rim & Body & $\mathrm{N}$ \\
\hline
\end{tabular}

\section{Utility Ware}

Appliqued

Appliqued-incised

Brushed

Brushed-incised

Brushed-punctated

Incised

Neck banded-brushed

Punctated

Subtotal

$\begin{array}{rrr}- & 8 & 8 \\ - & 1 & 1 \\ 5 & 217 & 222 \\ 2 & 6 & 8 \\ - & 1 & 1 \\ 11 & 16 & 27 \\ - & 1 & 1 \\ 8 & 4 & 12 \\ 26 & 254 & 280\end{array}$

Fine Ware

Engraved

13

39

52

Totals

39

293

332

*does not include the 13 brushed sherds from the partial vessel section 
The decorated sherds are almost exclusively from grog-tempered vessels, as only $1.5 \%$ of the decorated sherds $(n=332)$ are from bone-tempered vessels. These few bone-tempered sherds are exclusively from the fine wares in the assemblage.

The rim sherds with brushing marks comprise $19.2 \%$ of the utility ware rims (Table 5 ). These rims have primarily vertical brushing (Figure 6d-e), and are probably from Bullard Brushed jars. Two other lower rim-body sherds have horizontal incised lines on the rim and vertical brushing on the vessel body.

Table 5. Decorative elements on utility ware rim sherds from the Gardener site.

\begin{tabular}{llr}
\hline Decorative element & N & $\%$ \\
\hline Diagonal to vertical brushing & 2 & 7.7 \\
Vertical brushing & 3 & 11.5 \\
& 2 & 7.7 \\
Horizontal incised on the rim and & & \\
$\quad$ vertical brushing on the body & 5 & 19.2 \\
& 3 & 11.5 \\
Diagonal incised lines & 2 & 7.7 \\
Diagonal opposed incised lines & 1 & 3.8 \\
Horizontal incised lines & 1 & 3.8 \\
Vertical incised lines & 6 & 23.1 \\
& 1 & 3.8 \\
Tool punctated row, mid-rim & 26 & 100.0 \\
Tool punctated row on thickened rim strip & & \\
\hline Tool punctated rows & & \\
\hline Totals & & \\
\hline
\end{tabular}

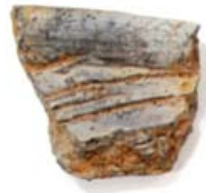

a

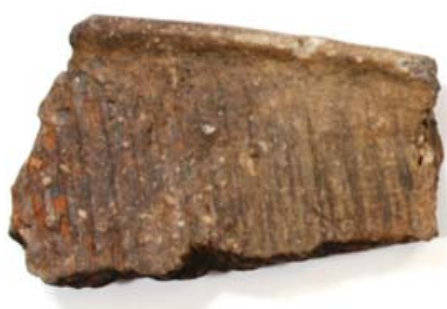

e

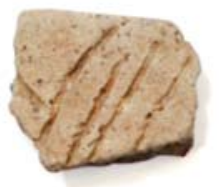

b

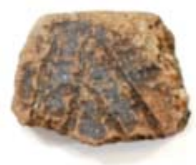

C

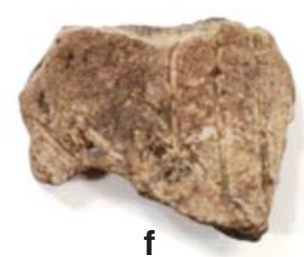

f

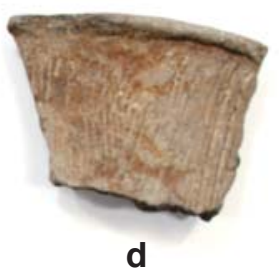

d

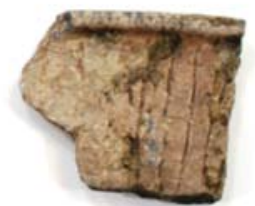

g

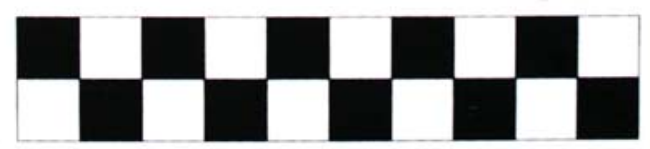

Figure 6. Incised and brushed sherds from the Gardener site: a-c, f-g, incised; d-e, brushed. 
Rims with incised lines primarily are from Maydelle Incised jars with diagonal, diagonal opposed, and vertical incised elements (see Figure 6a-c, f-g and Figure 7a). Other rims have sets of horizontal incised lines (see Table 5). Incised rim sherds comprise $43 \%$ of the utility ware rims from the Gardener site.
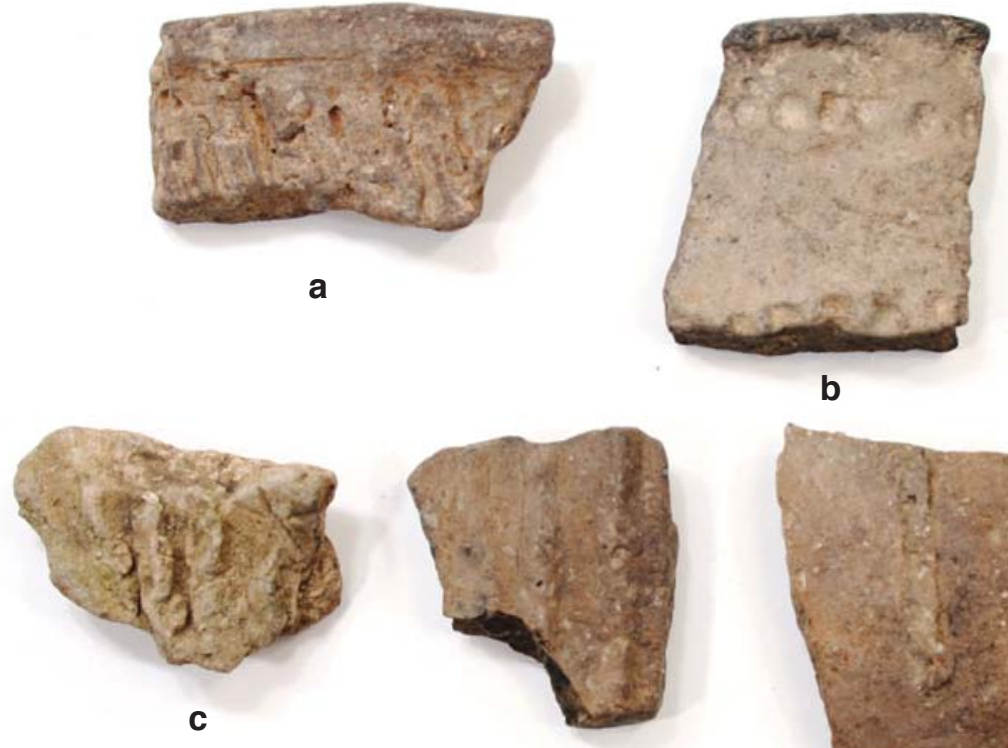

d

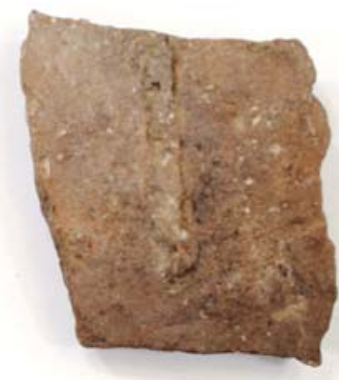

e

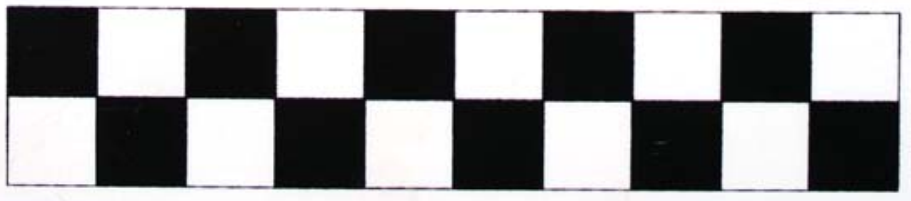

Figure 7. Utility ware sherds from the Gardener site: a, diagonal incised rim; b, tool punctated rim; c-e, appliqued body sherds.

Rims with tool punctates comprise $30.8 \%$ of the utility ware rims from the site (see Table 5). Several have one or more rows of tool punctates on the rim itself (see Figure 7b). Most of the tool punctated rim sherds are from vessels with a distinctive exterior thickened rim strip that has a row of triangular-shaped tool punctates on the rim strip, just below the lip (Figure 8). These rim sherds are from Gardener Punctated jars, a new East Texas Caddo pottery type. At least one other site at Lake Bob Sandlin has Gardener Punctated sherds, but its distribution within the Big Cypress Creek basin is not currently known.

Among the utility body sherds, there are several other distinctive decorative elements in the Gardener site assemblage. A number of body sherds have straight or curvilinear appliqued ridges $(n=8$, see Figure $7 \mathrm{c}-\mathrm{e})$; one body sherd has a straight appliqued ridge and parallel incised lines; and there are brushed sherds with tool punctates pushed through the brushing $(n=1)$; this sherd is likely from a Pease Brushed-Incised jar.

The engraved fine ware sherds are from Ripley Engraved and Taylor Engraved carinated bowls, compound bowls, and bottles, with Ripley Engraved being especially well represented in the Gardener site assemblage. Among the engraved rim sherds, decorative elements found on Ripley Engraved vessels (see Perttula et al. 2012:Figure 5a-k; Suhm and Jelks 1962:Plates 64-65; Thurmond 1990:Figure 6) are dominant, including slanting scrolls and scroll and circle motifs (Table 6 and Figure 9a, d-e) on carinated bowls. 

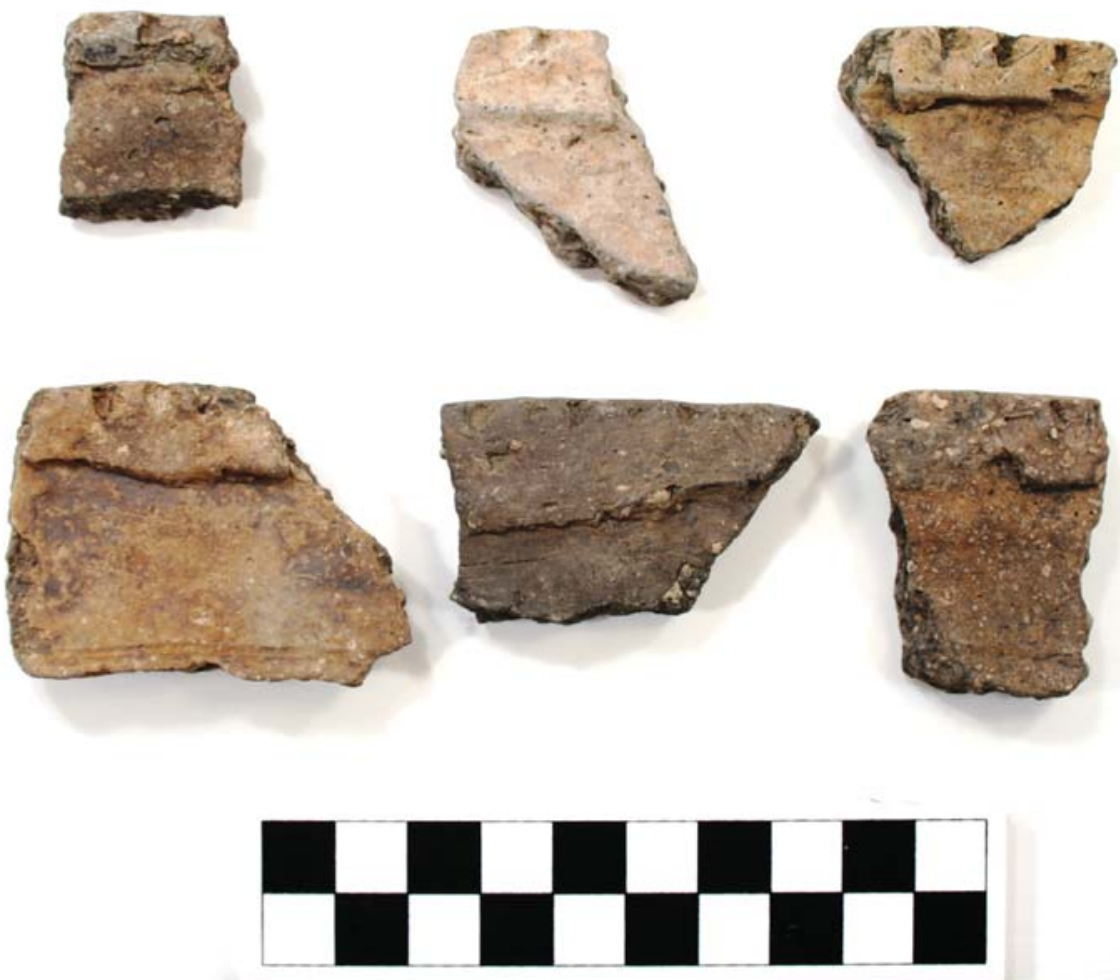

Figure 8. Gardener Punctated rim sherds.

Table 6. Decorative elements on fine ware rim sherds from the Gardener site.

\begin{tabular}{lcc}
\hline Decorative element & N & $\%$ \\
\hline Circle element & 2 & 15.4 \\
Circle element and slanting scroll & 1 & 7.7 \\
Horizontal engraved lines & 2 & 15.4 \\
Horizontal engraved line and excised pendant triangles & 1 & 7.7 \\
Scroll fill zones & 1 & 7.7 \\
Semi-circle elements & 1 & 7.7 \\
Semi-circular lines and excised zones & 1 & 7.7 \\
Slanting scroll engraved lines & 4 & 30.8 \\
\hline Totals & 13 & 100.0 \\
\hline
\end{tabular}

Other Ripley Engraved carinated bowl motifs include a negative oval in a scroll fill zone (see Figure $9 \mathrm{~b}$ ), a rim sherd with portions of a scroll and an excised pendant triangle above the scroll (Ripley Engraved, cf. var. Gandy, see Perttula et al. 2012), semi-circle elements, and hatched triangles. One Taylor Engraved body sherd has a hooked arm element (see Suhm and Jelks 1962:149). Two engraved rim sherds are from compound bowls. One has horizontal engraved lines on an upper panel (see Figure 9c), while the other has a series of concentric semi-circular lines and excised zones (see Figure 9f). This latter sherd is from a vessel of an unknown type. 


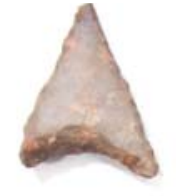

a
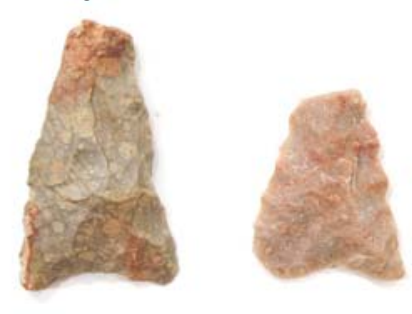

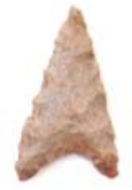

b

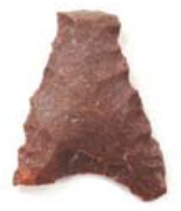

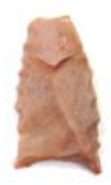

C

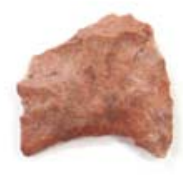

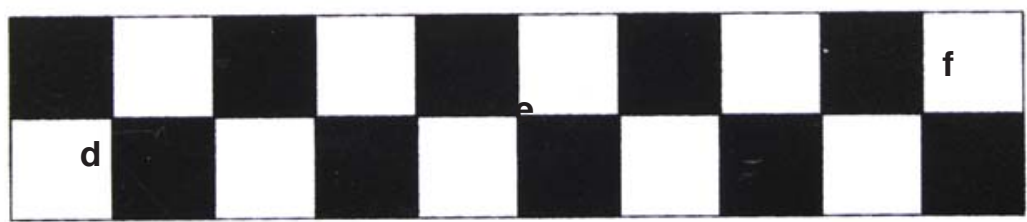

Figure 9. Ripley Engraved rim and body sherds from the Gardener site: a-b, d-e, carinated bowl sherds; c, f, compound bowl sherds.

\section{Partial Vessel Section}

The partial vessel section is a grog-tempered Bullard Brushed jar represented by 13 lower rim and body sherds. The lower rim has vertical brushing marks, while the vessel body has both vertical and diagonal brushing marks.

\section{SUMMARY AND CONCLUSIONS}

The Gardener site is located on a tributary to Big Cypress Creek in Lake Bob Sandlin in the Post Oak Savanna of East Texas. It is a multi-component site with evidence of limited use during the Late Archaic and Woodland periods, but with a substantial Late Caddo period, Titus phase settlement.

The site was first recorded in 1975 prior to the construction of Lake Bob Sandlin, but received no further investigations before the lake was built, even though the recovered artifacts indicated there was a burned Caddo house structure likely preserved there. The site has been reinvestigated in 2013 as it became exposed again because of lowered flood pool levels at the lake, and we have been able to document a substantial artifact assemblage from the Gardener site.

The artifact assemblage from the site is dominated by chipped stone tools and lithic debris, pieces of daub, and sherds from plain ware, utility ware, and fine ware ceramic vessels. The common occurrence of daub in the documented collected once again is notable. The lithic tools primarily include several kinds of Late Caddo style arrow points (most notably Maud points) and flake tools, and an abundance of lithic debris from local lithic raw material (mainly quartzite) sources comprised of pebbles in stream gravels. The ceramics 
are from grog and bone-tempered vessels. Among the utility wares are the types Bullard Brushed, Maydelle Incised, and Pease Brushed-Incised, as well as rim punctated, appliqued, and neck banded vessels among the utility wares - which comprise more than $84 \%$ of all the decorated sherds. A distinctive and new type of rim punctated vessel has also been identified at the site which we have called Gardener Punctated. Sherds from Ripley Engraved and Taylor Engraved vessels are among the fine wares, which occur on carinated bowls, compound bowls, and bottles. The principal motifs in the Ripley Engraved fine wares are scrolls and scroll and circles, which may suggest the Titus phase component at the Gardener site was a farmstead that was occupied between ca. A.D. 1450-1550.

\section{REFERENCES CITED}

Perttula, T. K., B. Nelson, and M. Walters

2012 Caddo Archaeology at the Henry Spencer Site (41UR315) in the Little Cypress Creek Basin of East Texas. Special Publication No. 20. Friends of Northeast Texas Archaeology, Pittsburg and Austin.

Suhm, D. A. and E. B. Jelks (editors)

1962 Handbook of Texas Archeology: Type Descriptions. Special Publication No. 1, Texas Archeological Society, and Bulletin No. 4, Texas Memorial Museum, Austin.

Sullivan, T. L.

1977 Archaeological Investigations at Lake Bob Sandlin, Texas. Research Report No. 99. Archaeology Research Program, Southern Methodist University, Dallas.

Thurmond, J. P.

1990 Archeology of the Cypress Creek Drainage Basin, Northeastern Texas and Northwestern Louisiana. Studies in Archeology 5. Texas Archeological Research Laboratory, The University of Texas at Austin. 